\title{
ANALISIS PENDAPATAN NELAYAN PENCARI KERANG TIRAM DI DESA KUALA LANGSA KECAMATAN LANGSA BARAT KOTA LANGSA
}

\author{
Cut Gustianal, Abdurrachman ${ }^{2}$ dan Muhammad Adri ${ }^{2}$ \\ ${ }^{1}$ Dosen Fakultas Pertanian Universitas Samudra \\ ${ }^{2}$ Dosen Fakultas Pertanian Universitas Samudra \\ ${ }^{2}$ Mahasiswa Program Studi Agribisnis Fakultas Pertanian Universitas Samudra
}

\begin{abstract}
ABSTRAK
Tujuan penelitian adalah untuk mengetahui besarnya pendapatan nelayan kerang tiram di Desa Kuala Langsa Kecamatan Langsa Barat Kota Langsa. Penelitian ini dilakukan di Desa Kuala Langsa Kecamatan Langsa Barat Kota Langsa dengan pertimbangan bahwa Desa Kuala Langsa Kecamatan Langsa Barat Kota Langsa merupakan salah satu daerah pesisir yang ada di Kota Langsa yang mayoritas penduduknya berprofesi sebagai nelayan. Objek dalam penelitian ini dibatasi pada nelayan pencari kerang tiram di wilayah Desa Kuala Langsa Kecamatan Langsa Barat Kota Langsa. Ruang lingkup penelitian ini meliputi produksi, harga jual, total penerimaan, dan pendapatan nelayan pencari kerang tiram di Desa Kuala Langsa Kecamatan Langsa Barat Kota Langsa. Waktu penelitian dilaksanakan pada bulan April sampai Mei 2018. Pengambilan sampel dengan menggunakan metode Simple Random Sampling dengan teknik pengambilan secara acak.

Hasil penelitian menunjukkan bahwa Rata-rata umur nelayan pencari kerang tiram di Desa Kuala Langsa Kecamatan Langsa Barat Kota Langsa adalah 38,99 tahun, masa pendidikan rata-rata 7,49 tahun, pengalaman nelayan rata-rata 7,24 tahun dan jumlah tanggungan rata-rata 3 orang. Rata-rata penggunaan tenaga kerja nelayan pencari kerang tiram sampel di Desa Kuala Langsa Kecamatan Langsa Barat Kota Langsa yaitu sebesar 1,03 HKP dengan biaya tenaga kerja sebesar Rp. 130.022/bulan. Rata-rata produksi nelayan pencari kerang tiram di Desa Kuala Langsa Kecamatan Langsa Barat Kota Langsa yaitu sebanyak 76 kg/bulan. Rata-rata biaya produksi yang harus dikeluarkan oleh nelayan pencari kerang tiram adalah Rp. 753.509/bulan. Rata-rata nilai produksi nelayan pencari kerang tiram adalah Rp. 1.668.292/bulan. Rata-rata pendapatan bersih nelayan pencari kerang tiram sampel di Desa Kuala Langsa Kecamatan Langsa Barat Kota Langsa yaitu sebesar Rp. 914.783/bulan. Pendapatan bersih nelayan pencari kerang tiram di Desa Kuala Langsa Kecamatan Langsa Barat Kota Langsa masih berada dalam kategori rendah karena jika dibandingkan dengan tingkat pendapatan sesuai Upah Minimum Regional Kota Langsa yaitu sebesar Rp.2.700.000 per bulan.
\end{abstract}

Kata kunci: nelayan pencari kerang tiram, harga, produksi, pendapatan.

\section{PENDAHULUAN}

Salah satu Provinsi di Indonesia ialah Provinsi Aceh, Aceh merupakan salah satu provinsi di Indonesia yang memiliki potensi terbesar di bidang perairan hasil laut tangkap sebesar 153,692 ton. Pada tahun 2013 jumlah hasil laut tangkap di Provinsi Aceh sebesar 153,692 ton (BPS, 2013). Salah satu daerah pesisir di Provinsi Aceh adalah Kota Langsa tepatnya di Desa Kuala Langsa. Desa Kuala Langsa merupakan daerah pesisir Kota Langsa yang sebagian besar penduduk nya bermata pencaharian sebagai Nelayan.

Salah satu potensi hasil laut di Indonesia adalah kerang tiram berdasarkan data statistik Kementrian Kelautan dan
Perikanan tahun 2011, volume produksi kerang (kerang darah, kerang hijau, Tiram simping, kerang mutiara, Remis) sebesar 54.801 ton dan tahun 2012 sebesar 50.460 ton sedangkan untuk nilai produksi kerang tahun 2011 sebesar Rp. 448.996.881 dan tahun 2012 sebesar Rp.435.728.094. Produksi kerang tiram di Indonesia dalam dua tahun belakang mengalami penurunan sebesar 2,96\% (Kementrian Kelautan dan Perikanan,2012).

Salah satu penyebab penurunan nilai produksi kerang tiram di Indonesia adalah alat tangkapan yang digunakan nelayan yang masih bersifat tradisional. Penurunan produksi nilai kerang tiram akan berdampak 
pada penurunan pendapatan nelayan kerang tiram.

Berdasarkan pra survei yang sudah dilakukan peneliti, jumlah KK yang bermata pencaharian sebagai nelayan mencapai $95 \%$ yaitu sebanyak 523 KK sedangkan sisanya sebesar 5\% bekerja diluar dari sektor perikanan seperti pegawai negeri sipil (PNS), supir mobil rental, dan tukang becak. Jumlah nelayan yang bekerja sebagai pencarikerang tiram sebanyak $60 \mathrm{KK}$ dari $523 \mathrm{KK}$. Dimana nelayan yang mencari kerang tiram tersebar di empat dusun di Desa Kuala Langsa yakni, Dusun Damai, Dusun Harapan, Dusun Iklhas, dan Dusun Setia. Selain dari hasil melaut beberapa nelayan kerang tiram mempunyai pekerjaan sampingan seperti berjualan mie aceh dan membuka warung di depan rumah nya, Sisanya sebesar $463 \mathrm{KK}$ sebagai pencari hasil laut lainnya seperti ikan, udang, dan kepiting.

Dominasi nelayan yang bermata pencaharian sebagai pencari kerang tiram terdapat pada Dusun Harapan. Pendapatan nelayan pencari kerang tiram di Desa Kuala Langsa masih tergolong rendah dilihat dari sosial ekonomi yang rendah serta alat tangkap kerang tiram yang masih tergolong tradisional. Oleh karena itu, berdasarkan latar belakang diatas penulis tertarik untuk menganalisa pendapatan nelayan kerang tiram di Desa Kuala Langsa Kecamatan Langsa Barat Kota Langsa.

\section{Identifikasi Masalah}

Berapa besar pendapatan Nelayan pencari kerang tiram di Desa Kuala Langsa Kecamatan Langsa Barat Kota Langsa.

\section{TujuanPenelitian}

Untuk mengetahui besarnya pendapatan nelayan kerang tiram di Kecamatan Langsa Barat Kota Langsa.

\section{Hipotesis}

Pendapatan nelayan pencari kerang tiram di Desa Kuala Langsa Kecamatan Langsa Barat Kota Langsa rendah dilihat dari ketegori UMR Kota Langsa.

\section{METODE PENELITIAN}

Lokasi, Objek, Ruang Lingkup dan Waktu Penelitian $\begin{array}{ccc}\text { Metode } & \text { yang } & \text { digunakan } \\ \text { penelitian } & \text { ini alam } & \text { adalah metode }\end{array}$ survei.Menurut Nazir (2009:550), "Metode survei adalah penyelidikan untuk memperoleh fakta dari gejala-gejala dan mencari keterangan-keterangan secara faktual, baik tentang institusi sosial, ekonomi ataupun politik dari suatu kelompok atau suatu daerah"'. Lokasi penelitian yaitu di Desa Kuala Langsa Kecamatan Langsa Barat Kota Langsa. Dengan pertimbangan desa tersebut merupakan desa pesisir yang sebagian besar masyarakatnya bekerja sebagai nelayan.

Objek dalam penelitian ini dibatasi pada nelayan pencari kerang tiram di wilayah Desa Kuala Langsa Kecamatan Langsa Barat Kota Langsa. Ruanglingkup penelitian ini meliputi produksi, harga jual, total penerimaan, dan pendapatan nelayan pencari kerang tiram di Desa Kuala Langsa Kecamatan Langsa Barat Kota Langsa. Waktu penelitian dilaksanakan pada bulan April sampai Mei 2018.

\section{Populasi Dan Sampel Penelitian}

Kecamatan Langsa Barat Kota Langsa terdapat 13 Desa. Salah satu desa di Kecamatan Langsa Barat Kota Langsa Adalah Kuala Langsa. Desa Kuala Langsa merupakan desa penghasil tangkapan laut seperti kerang tiram. Populasi pada penelitian ini adalah semua nelayan pencari kerang tiram di Desa Kuala Langsa sebanyak 60 orang. Pengambilan sampel dengan menggunakan metode Simple Random Sampling dengan teknik pengambilan secara acak. Wiratha (2006:238) mengemukakan dalam sampel random sederhana, anggota populasi tidak di pilah-pilah atau starata terlebih dahulu. Populasi dipilih secara random (acak), peneliti langsung mengacak untuk ukuran sampel yang diinginkan, jumlah populasi nelayan diambil dari kantor Desa Kuala Langsa Kecamatan Langsa Barat Kota Langsa saat peneliti melakukan pra survei di desa tersebut. Kemudian dari jumlah populasi diambil $50 \%$ untuk dijadikan sampel, sehingga diperoleh sampel nelayan sebanyak 30 orang. 
Tabel III-1 : Jumlah Populasi dan Sampel Nelayan Pencari Kerang Tiram di Desa Kuala Langsa Kecamatan Langsa Barat Tahun 2018.

\begin{tabular}{|c|l|c|c|}
\hline No & \multicolumn{1}{|c|}{ Nama Dusun } & Populasi (Orang) & Sampel (Orang) \\
\hline 1 & Harapan & 20 & 9 \\
2 & Ikhlas & 12 & 6 \\
3 & Setia & 13 & 7 \\
4 & Damai & 15 & 8 \\
\hline \multicolumn{2}{|c|}{ Jumlah } & 60 & 30 \\
\hline
\end{tabular}

Sumber : Data Primer, 2018 (diolah)

\section{Variabel dan Data yang Dianalisis}

Variabel merupakan segala sesuatu yang berbentuk apa saja yang ditetapkan peneliti untuk dipelajari sehingga diperoleh informasi tentang hal tersebut (Sugiyono, 2010:212). Variabel dalam penelitian ini adalah:
a. Produksi $(\mathrm{Rp} / \mathrm{Kg})$
b. Harga $(\mathrm{Rp} / \mathrm{Kg})$
c. Biaya produksi (Rp/Bln)
d. Penggunaan Tenaga Kerja (Rp/HKP)
e. Penerimaan atau Pendapatan kotor (Rp/Bln)
f. Keuntungan atau pendapatan bersih(Rp/Bln)

\section{Metode Analisis dan Pengujian Hipotesis}

Untuk menganalisis pendapatan nelayan kerang tiram digunakan rumus sebagai berikut:

\section{a. Analisis biaya produksi}

Biaya produksi adalah keseluruhan biaya produksi ekonomi yang dibutuhkan dalam kegiatan produksi suatu barang.

Analisis biaya produksi dihitung menggunakan rumus:

$\mathrm{TC}=\mathrm{FC}+\mathrm{VC}$.........(M.Firdaus 2008:63)

Keterangan:

$\mathrm{TC}=$ Total Cost $($ total biaya $)(\mathrm{Rp} / \mathrm{Bln})$

$\mathrm{FC}=$ Fixed Cost (biaya tetap) $(\mathrm{Rp} / \mathrm{B} \ln )$

$\mathrm{VC}=$ Variable Cost (biaya tidak tetap) (Rp/Bln)

b. Pendapatan atau penerimaan

Pendapatan merupakan jumlah uang yang diterima oleh suatu perusahaan dari suatu aktivitas yang dilakukan.

$\mathrm{TR}=\mathrm{Q} \times \mathrm{P}$.............(M.Firdaus 2008:63)

Keterangan:
$\mathrm{TR}=$ Total Revenue (Penerimaan total) (Rp/Bln)

$\mathrm{Q} \quad=$ Quality (Jumlah produk yang dihasilkan) $(\mathrm{Kg})$

$\mathrm{P}=$ Price $($ Harga $)(\mathrm{Rp} / \mathrm{Kg})$

c. Keuntungan

Keuntungan ialah pendapatan bersih yang diterima oleh nelayan dari produksi dilakukannya.

$\pi=T R-T C$

(Soekarwati,2002: 58)

Keterangan:

$\pi=$ Keuntungan $(\mathrm{Rp} / \mathrm{Bln})$

$\mathrm{TR}=$ Total Revenue (Total Pendapatan) $(\mathrm{Rp} / \mathrm{B} \ln )$

$\mathrm{TC}=$ Total Cost $($ Total biaya $)(\mathrm{Rp} / \mathrm{B} \ln )$

\section{HASIL DAN PEMBAHASAN \\ Karakteristik Responden}

Karakteristik nelayan kerang tiram yang dimaksud dalam penelitian ini meliputi: umur, pendidikan, pengalaman bekerja dan jumlah tanggungan keluarga. Umur sangat mempengaruhi kemampuan fisik seseorang, baik dalam berpikir maupun dalam bekerja. Pendidikan sangat mempengaruhi cara berfikir seseorang sehingga dapat mengembangkan kemampuan yang dimiliki. Pengalaman seseorang juga berpengaruh terhadap pekerjaannya. Besarnya jumlah tanggungan keluarga merupakan faktor yang mempengaruhi kemauan untuk melakukan pekerjaan. Untuk lebih jelasnya mengenai karakteristik nelayan kerang tiram dapat dilihat pada tabel V-1 berikut ini : 
Tabel V-1: Rata-rata Karakteristik Nelayan Kerang Tiram di Desa Kuala Langsa Kecamatan Langsa Barat Kota Langsa, 2018.

\begin{tabular}{|c|l|c|c|c|c|}
\hline No & \multicolumn{1}{|c|}{ Dusun } & $\begin{array}{c}\text { Umur } \\
\text { (Tahun) }\end{array}$ & $\begin{array}{c}\text { Pendidikan } \\
\text { (Tahun) }\end{array}$ & $\begin{array}{c}\text { Pengalaman } \\
\text { (Tahun) }\end{array}$ & $\begin{array}{c}\text { Tanggungan } \\
\text { (Orang) }\end{array}$ \\
\hline 1 & Harapan & 40,33 & 6,67 & 9,44 & 3 \\
2 & Ikhlas & 38,50 & 8,50 & 8,83 & 3 \\
3 & Setia & 34,00 & 7,29 & 4,57 & 4 \\
4 & Damai & 43,13 & 7,50 & 6,13 & 3 \\
& & & & 7,24 & 3 \\
\hline
\end{tabular}

Sumber : Data Primer, 2018 (diolah)

Dari tabel V-1 di atas dapat dilihat bahwa rata-rata umur nelayan pencari kerang tiram di Desa Kuala Langsa Kecamatan Langsa Barat Kota Langsa adalah 38,99 tahun, umur tersebut merupakan umur yang produktif dalam menjalankan kegiatan sebagai nelayan. Ini sesuai dengan pernyataan daeljoeni (1987:74) yang menyatakan bahwa umur produktif penuh dimulai dari umur 20-54 tahun. Masa pendidikan rata-rata nelayan kerang tiram yang menjadi sampel di Desa Kuala Langsa adalah 7,49 tahun dan ini setara dengan pendidikan SMP dengan demikian tingkat pendidikan nelayan pencari kerang tiram masih tergolong rendah menurut UndangUndang No 20 Tahun 2003.

Pengalaman nelayan kerang tiram dalam pekerjaannya rata-rata 7,24 tahun dan ini terbilang cukup dalam melakukan pekerjaannya. Dengan jumlah tanggungan rata-rata 3 orang yang berarti tanggungan keluarga nelayan pencari kerang tiram tergolong kecil apabila jumlah tanggungan kurang dari 5 orang menurut Abu Ahmadi ( 2002:231)

\section{Penggunaan Tenaga Kerja}

Tenaga kerja yang digunakan oleh nelayan pencari kerang tiram di Desa Kuala Langsa berasal dari tenaga kerja dalam keluarga dan luar keluarga yang terdiri dari pria dan wanita. Penggunaan tenaga kerja oleh nelayan pencari kerang tiram yakni untuk mencari tiram dan untuk mengupas tiram.Untuk setiap kegiatan seluruhnya dikonversikan ke dalam Hari kerja pria (HKP). Rata-rata penggunaan tenaga kerja nelayan pencari kerang tiram di Desa Kuala Langsa dapat dilihat pada tabel V-2 berikut ini :

Tabel V-2 Rata-rata Penggunaan Tenaga Kerja Nelayan Pencari Kerang Tiram Sampel di Desa Kuala Langsa Kecamatan Langsa Barat Kota Langsa, 2018.

\begin{tabular}{|c|c|c|c|c|c|c|c|}
\hline \multirow[b]{2}{*}{ No } & \multirow[b]{2}{*}{ Dusun } & \multicolumn{2}{|c|}{$\begin{array}{c}\text { Jenis Kegiatan } \\
(\mathrm{HKP})\end{array}$} & \multirow{2}{*}{$\begin{array}{l}\text { Jumlah } \\
\text { (HKP) }\end{array}$} & \multirow{2}{*}{$\begin{array}{c}\text { Upah TK } \\
\text { pencari } \\
\text { Tiram } \\
(\mathrm{Rp} / \mathrm{HKP})\end{array}$} & \multirow{2}{*}{$\begin{array}{c}\text { Upah TK } \\
\text { Pengupas } \\
\text { Tiram } \\
\text { (RP/HKP) }\end{array}$} & \multirow{2}{*}{$\begin{array}{c}\text { Biaya } \\
\text { Tenaga } \\
\text { Kerja } \\
\text { (Rp/Bulan) }\end{array}$} \\
\hline & & $\begin{array}{r}\text { Pencari } \\
\text { Tiram }\end{array}$ & $\begin{array}{c}\text { Pengupas } \\
\text { Tiram }\end{array}$ & & & & \\
\hline 1 & Harapan & 0,64 & 0,41 & 1,05 & 7.000 & 5.222 & 131.578 \\
\hline 2 & Ikhlas & 0,63 & 0,38 & 1,01 & 7.000 & 5.333 & 128.867 \\
\hline 3 & Setia & 0,64 & 0,39 & 1,03 & 7.000 & 5.000 & 128.543 \\
\hline 4 & Damai & 0,66 & 0,37 & 1,03 & 7.000 & 5.250 & 131.100 \\
\hline \multicolumn{2}{|c|}{ Rata-rata } & 0,64 & 0,39 & 1,03 & 7.000 & 5.201 & 130.022 \\
\hline
\end{tabular}

Sumber : Data Primer, 2018 (diolah)

Tabel V-2 di atas dapat dilihat bahwa ratarata penggunaan tenaga kerja nelayan pencari kerang tiram sampel di Desa Kuala Langsa Kecamatan Langsa Barat Kota Langsa yaitu sebesar 1,03 HKP dengan biaya tenaga kerja sebesar Rp. 130.022/bulan. Penggunaan tenaga kerja paling besar terdapat di Dusun Harapan yaitu sebesar 1,05 HKP dengan 
biaya tenaga kerja sebesar Rp. 131.578/bulan ini disebabkan karena dusun tersebut merupakan dusun yang paling banyak terdapat produksi kerang tiram di Desa Kuala Langsa sehingga memerlukan banyak tenaga kerja dalam mencari tiram.

Penggunaan tenaga kerja terkecil yaitu Dusun Ikhlas sebesar 1,01 HKP dengan biaya tenaga kerja sebesar Rp. 128.867/bulan. Upah yang diperoleh dari mencari tiram yaitu sebesar Rp.7.000/HKP dan upah yang diperoleh dari mengupas tiram yaitu $\mathrm{Rp}$. 5.201/HKP.

\section{Produksi Nelayan Kerang Tiram}

Produksi yang dimaksud dalam penelitian ini adalah hasil fisik yang diperoleh dari nelayan yakni kerang tiram.Rata-rata produksi nelayan pencari kerang tiram sampel di Desa Kuala Langsa Kecamatan Langsa Barat Kota Langsa dapat dilihat pada tabel V-3 berikut ini:

Tabel V-3 Rata-rata Produksi Nelayan Pencari Kerang Tiram Sampel di Desa Kuala Langsa Kecamatan Langsa Barat Kota Langsa, 2018.

\begin{tabular}{|c|l|c|}
\hline No & \multicolumn{1}{|c|}{ Dusun Sampel } & Produksi (Kg/Bulan) \\
\hline 1 & Harapan & 78 \\
2 & Ikhlas & 70 \\
3 & Setia & 77 \\
4 & Damai & 78 \\
& & 76 \\
\hline \multicolumn{2}{|c|}{ Rata-rata } \\
\hline
\end{tabular}

Sumber : Data Primer, 2018 (diolah)

Berdasarkan tabel V-3 dapat dilihat bahwa rata-rata produksi nelayan pencari kerang tiram di Desa Kuala Langsa Kecamatan Langsa Barat Kota Langsa yaitu sebanyak 76 $\mathrm{kg} / \mathrm{bulan}$. Rata-rata produksi kerang tiram tertinggi berada di Dusun Harapan dan Dusun Damai yaitu sebesar $78 \mathrm{~kg} / \mathrm{bulan}$ dan produksi kerang tiram terendah berada di Dusun Ikhlas yaitu sebanyak $70 \mathrm{~kg} / \mathrm{bulan}$. Produksi kerang tiram rendah disebabkan karena di Dusun Ikhlas, nelayan pencari kerang tiram lebih sedikit dibandingkan nelayan pencari kerang tiram di dusun lain. Mata pencarian penduduk di Dusun Ikhlas lebih banyak berdagang dengan membuka warung di depan rumah.

\section{Biaya Produksi Nelayan Kerang Tiram}

Biaya produksi dalam penelitian ini diklasifikasikan menjadi dua yaitu biaya tetap (fixed cost) dan biaya tidak tetap (variable cost). Biaya tetap dalam penelitian ini adalah biaya penyusutan alat berupa parang, ember, jaring, sarung tangan, serta tempat pembakaran yang mereka buat sendiri dengan menggunakan kayu dan biaya ongkos sewa bot.

Sedangkan biaya tidak tetap meliputi biaya untuk bekal makanan yang mereka bawa saat mencari tiram serta upah tenaga kerja. Untuk lebih jelasnya mengenai ratarata penggunaan biaya produksi nelayan kerang tiram pada nelayan sampel di Desa Kuala Langsa di Kecamatan Langsa Barat Kota Langsa dapat dilihat pada tabel V-4 berikut ini :

Tabel V-4 Rata-rata Biaya Produksi Nelayan Pencari Kerang Tiram Sampel di Desa Kuala Langsa Kecamatan Langsa Barat Kota Langsa, 2018.

\begin{tabular}{|c|c|c|c|c|}
\hline \multirow{2}{*}{ No } & \multirow{2}{*}{ Dusun } & \multicolumn{2}{|c|}{ Biaya (Rp/Bulan) } & \multirow{2}{*}{$\begin{array}{l}\text { Biaya Produksi } \\
\text { (Rp/Bulan) }\end{array}$} \\
\hline & & Biaya Tetap & Biaya Variabel & \\
\hline 1 & Harapan & 470.444 & 293.800 & 764.244 \\
\hline 2 & Ikhlas & 474.782 & 295.533 & 770.316 \\
\hline 3 & Setia & 448.937 & 282.829 & 731.765 \\
\hline 4 & Damai & 459.111 & 288.600 & 747.711 \\
\hline & Rata-rata & 463.319 & 290.190 & 753.509 \\
\hline
\end{tabular}

Sumber : Data Primer, 2018 (diolah) 
Berdasarkan tabel V-4 dapat dilihat bahwa rata-rata biaya produksi yang harus dikeluarkan oleh nelayan pencari kerang tiram adalah Rp. 753.509/bulan. Terdiri dari biaya tetap sebesar Rp. 463.319/bulan dan biaya variabel sebesar Rp. 290.190/bulan. Dari biaya tersebut, penggunaan biaya produksi terbesar yaitu Dusun Ikhlas sebesar Rp. 770.316/bulan. Dan penggunaan biaya produksi terendah yaitu di Dusun Setia sebesar Rp. 731.765/bulan.

Tabel V-5 Rata-rata Nilai Produksi Nelayan Pencari Kerang Tiram Sampel di Desa Kuala Langsa Kecamatan Langsa Barat Kota Langsa, 2018.

\begin{tabular}{|c|l|c|c|c|}
\hline No & \multicolumn{1}{|c|}{ Dusun } & $\begin{array}{c}\text { Produksi } \\
(\mathrm{Kg} / \mathrm{bulan})\end{array}$ & Harga $(\mathrm{Rp} / \mathrm{Kg})$ & $\begin{array}{c}\text { Nilai Produksi } \\
(\mathrm{Rp} / \mathrm{bulan})\end{array}$ \\
\hline 1 & Harapan & 78 & 19.778 & 1.538 .272 \\
2 & Ikhlas & 70 & 20.500 & 2.234 .500 \\
3 & Setia & 77 & 19.429 & 1.379 .459 \\
4 & Damai & 78 & 19.625 & 1.520 .938 \\
\hline \multicolumn{2}{|c|}{ Rata-rata } & 76 & 19.833 & 1.668 .292 \\
\hline
\end{tabular}

Sumber : Data Primer, 2018 (diolah)

Dari tabel V-5 dapat dilihat bahwa rata-rata nilai produksi nelayan pencari kerang tiram adalah Rp. 1.668.292/bulan. Nilai produksi yang diperoleh bisa saja meningkat bisa saja menurun tergantung dengan hasil yang diperoleh dan tingkat harga yang berlaku saat itu. Nilai produksi tertinggi berada di Dusun Ikhlas yaitu sebesar Rp. 2.234.500/bulan ini disebabkan harga jual di Dusun Ikhlas juga tinggi karena merka menjual langsung ke konsumen. Nilai produksi terkecil berada di

\section{Nilai Produksi (Pendapatan Kotor) Nelayan Pencari Kerang Tiram}

Besarnya nilai produksi sangat ditentukan oleh harga yang berlaku pada saat nelayan menjual hasil tangkapannya. Ratarata nilai produksi nelayan kerang tiram di Desa Kuala Langsa Kecamatan Langsa Barat Kota Langsa dapat dilihat pada tabel V-5 berikut ini :

Tabel V-6 Rata-rata Nilai Produksi Nelayan Pencari Kerang Tiram Sampel di Desa Kuala Langsa Kecamatan Langsa Barat Kota Langsa, 2018.

\begin{tabular}{|c|l|c|c|c|}
\hline No & \multicolumn{1}{|c|}{ Dusun } & $\begin{array}{c}\text { Nilai Produksi } \\
\text { (Rp/bulan) }\end{array}$ & $\begin{array}{c}\text { Biaya Produksi } \\
\text { (Rp/Bulan) }\end{array}$ & $\begin{array}{c}\text { Pendapatan Bersih } \\
\text { (Rp/Bulan) }\end{array}$ \\
\hline 1 & Harapan & 1.538 .272 & 764.244 & 774.027 \\
2 & Ikhlas & 2.234 .500 & 770.316 & 1.464 .184 \\
3 & Setia & 1.379 .459 & 731.765 & 647.694 \\
4 & Damai & 1.520 .938 & 747.711 & 773.226 \\
\hline \multicolumn{2}{|c|}{ Rata-rata } & 1.668 .292 & 753.509 & 914.783 \\
\hline
\end{tabular}

Sumber : Data Primer, 2018 (diolah)

Berdasarkan tabel V-6 dapat dilihat bahwa rata-rata pendapatan bersih nelayan pencari kerang tiram sampel di Desa Kuala Langsa Kecamatan Langsa Barat Kota Langsa yaitu sebesar Rp. 914.783/bulan. Rata-rata pendapatan bersih tertinggi berada di Dusun
Dusun Setia yaitu sebesar Rp. 1.379.459/bulan.

\section{Pendapatan Bersih Nelayan Pencari Kerang Tiram}

Pendapatan bersih yaitu selisih antara nilai produksi dengan total biaya produksi. Rata-rata pendapatan bersih nelayan pencari kerang tiram sampel di Desa Kuala Langsa Kecamatan Langsa Barat Kota Langsa dapat dilihat pada tabel V-6 berikut ini : 
dibandingkan dengan tingkat pendapatan sesuai Upah Minimum Regional Kota Langsa yaitu sebesar Rp.2.700.000 per bulan.

\section{KESIMPULAN DAN SARAN \\ Kesimpulan}

1. Rata-rata umur nelayan pencari kerang tiram di Desa Kuala Langsa Kecamatan Langsa Barat Kota Langsa adalah 38,99 tahun dengan masa pendidikan rata-rata 7,49 tahun. Sedangkan pengalaman nelayan kerang tiram dalam pekerjaannya rata-rata 7,24 tahun dengan jumlah tanggungan rata-rata 3 orang.

2. Rata-rata penggunaan tenaga kerja nelayan pencari kerang tiram sampel di Desa Kuala Langsa Kecamatan Langsa Barat Kota Langsa yaitu sebesar 1,03 HKP dengan biaya tenaga kerja sebesar Rp. 130.022/bulan.

3. Rata-rata produksi nelayan pencari kerang tiram di Desa Kuala Langsa Kecamatan Langsa Barat Kota Langsa yaitu sebanyak $76 \mathrm{~kg} / \mathrm{bulan}$.

4. Rata-rata biaya produksi yang harus dikeluarkan oleh nelayan pencari kerang tiram adalah Rp. 753.509/bulan. Terdiri dari biaya tetap sebesar Rp. 463.319/bulan dan biaya variabel sebesar Rp. 290.190/bulan.

5. Rata-rata nilai produksi nelayan pencari kerang tiram adalah Rp. 1.668.292/bulan.

6. Rata-rata pendapatan bersih nelayan pencari kerang tiram sampel di Desa Kuala Langsa Kecamatan Langsa Barat Kota Langsa yaitu sebesar Rp. 914.783/bulan. Pendapatan bersih nelayan pencari kerang tiram di Desa Kuala Langsa Kecamatan Langsa Barat Kota Langsa masih berada dalam kategori rendah karena jika dibandingkan dengan tingkat pendapatan sesuai UMR Regional yaitu sebesar Rp.2.700.000 per bulan.

\section{Saran}

1. Sebaiknya pemerintah memberikan bantuan seperti alat tangkap ataupun alat transportasi sehingga dapat mendukung para nelayan guna meningkatkan hasil tangkapan mereka.
2. Pihak-pihak terkait dapat memberikan solusi dengan melakuka penyuluhan kepada para nelayan untuk dapat meningkatkan pendapatannya selain daripada melaut.

\section{DAFTAR PUSTAKA}

Abu Ahmadi. 2002. Psikologi Sosial. Jakarta. Rineka Cipta.

Adrim, M.Fahmi. 2010. Panduan Penelitian Untuk Ikan Laut. Pusat Penelitian Oseanografi-LIPI.Jakarta.

Assauri, Sofjan. 2008. Manajemen Produksi Dan Operasi. Lembaga Penerbit Fakultas Ekonomi Universotas Indonesia. Jakarta.

Badan Pusat Statistik. 2011. Statistik Indonesia. Jakarta.

Badan Pusat Statistik. 2013. Produksi tangkapan laut.Aceh.

Basu Swastha, 2005. Manajemen Penjualan. BPFE. Yogyakarta.

Bustami, Nurlela. 2010. Akutansi Biaya. Edisi Kedua. Mitra Wacana Media. Jakarta.

Carter, W. K. 2009. Akuntansi Biaya. Edisi Keempat belas. Penerbit Salemba Empat. Cengage Learning Asia Pte. Ltd, Singapore. Jakarta.

Daldjoeni. 1987. Geografi Kota dan Desa. Bandung. Alumni.

Djaslim Saladin. 2001.Manajemen Pemasaran, Analisis, Perencanaan, Pelaksanaan dan Pengendalian. Penerbit :Lindakarya. Bandung.

Dyckman, Dukes dan Davis, 2000. Akuntansi Intermediate, Jilid 2, Erlangga. Jakarta

Fandy Tjiptono. 2005. Strategi Pemasaran. PT .ANDI OFFSET. Yogyakarta

Firdaus, Muhammad.2008. Manajemen Agribisnis, edisi satu, cetakan pertama. Bumi Aksara. Jakarta.

Food and Agriculture Organization (FAO). 2016. Cultured Aquatic Species Information Programme Oreochromis niloticus. FAO.

Hadi. 2000. Metodologi Research 2, Andi Offset. Yogyakarta.

Haliman R W, Adijaya DS. 2006. Udang Vaname. Penebar Swadaya. Jakarta.

Harsono. 2000. Pengertian Produksi. Djambatan. Jakarta. 
Heizer. Jay dan Barry Render. 2010. Operations ManagementManajemen Operasi. Edisi 9 Buku 2. Salemba Empat. Jakarta.

Imron dalam Subri. M 2005. Ekonomi Kelautan. Raja Grafindo Persada. Jakarta.

Kementrian Kelautan dan Perikanan. 2012. Statistik Perikanan Tangkap tahun 2011-2012. Kementrian Kelautan dan Perikanan. Jakarta.

Kordi. 2007. Pengelolaan Kualitas Air dalam Budidaya Perairan. Rineka Cipta, Jakarta.

Kotler, Amstrong.2001. Prinsip-Prinsip Pemasaran, Edisi keduabelas, Jilid1 . Erlangga. Jakarta.

Kusnadi. 2009. Masyarakat yang Hidup di Kawasan Pesisir. Ar-Ruzz Media. Yogyakarta.

Mubyarto. 2002.

PengantarEkonomiPertanian.

LP3ES. Jakarta.

Mulyadi. 2002. Pemeriksaan Akuntansi, Edisi ke-6. Jakarta.

Nazir, Moh. 2009. Metode Penelitian. Ghalia Indonesia.Jakarta.

Nirmalasari Idha. 2007. Analisis Kesesuaian Lahan Dan Pengembangan Kawasan Perikanan Budidaya Di Wilayah Pesisir Kabupaten Kutai Timur. Tesis. Sekolah Pascasarjana IPB. Bogor.
Niswonger. 2006. Prisip-prinsip Akutansi, Edisi Kesembilanbelas. Erlangga. Jakarta.

Sastrawidjaya. 2002. Nelayan Nusantara. Riset Pengolahan Produk Sosial Ekonomi Kelautan dan Perikanan. Jakarta.

Siagian, Sondang P. 2009. Kiat Meningkatkan Produktivitas Kerja. Rineka Cipta. Jakarta.

Siahainenia L. 2008. Bioekologi Kepiting Bakau (Scylla spp.) di Ekosistem Mangrove Kabupaten Subang, Jawa Barat. Disertasi Sekolah Pascasarjana, Institut Pertanian Bogor. Bogor.

Soekartawi. 2002. Prinsip-Prinsip Dasar Ekonomi Pertanian. PT. Raja Grafindo Persada : Jakarta.

Stice, Stice, Skousen. 2010. Akuntansi Keuangan, Buku I Edisi 16. PT Raja Grafindo Persada. Jakarta.

Suharti, T dan Fathorrozi. 2003. Teori Ekonomi Mikro dilengkapi beberapa bentuk fungsi produksi. Salemba Empat. Jakarta.

Sugiyono. 2010. Metode Penelitian Kuantitatif, Kualitatif dan $R \& D$. Alfabeta. Bandung.

Sugiyono, 2013. Metode Penelitian Kuantitatif, Kualitatif dan $R \& D$. Alfabeta.C. Bandung.

Wiratha. 2006 . Metodologi Penelitian Sosial Ekonomi. Yogyakarta. 